\title{
Primary Cervical Choriocarcinoma: Case Report and the Review of Literatures
}

\author{
N. Behtash, M. Karimi Zarchi", A. A. Shamshirsaz, A. A. Shamshirsaz, \\ Ashrafosadt Miratashi-Yazd, N. Mehrdad
}

Gynecological Oncology Fellowship, Shahid Sadoughi University of Medical Science, Yazd, Iran.

Email: *Drkarimi2001@yahoo.com

Received March 6 ${ }^{\text {th }}, 2013$; revised April 6 ${ }^{\text {th }}, 2013$; accepted April 14 ${ }^{\text {th }}, 2013$

Copyright (C) 2013 N. Behtash et al. This is an open access article distributed under the Creative Commons Attribution License, which permits unrestricted use, distribution, and reproduction in any medium, provided the original work is properly cited.

\begin{abstract}
Background: Primary choriocarcinoma of the cervix is a very rare entity. Case: A 35-year-old patient had been admitted to our hospital with vaginal bleeding for 7 months. A cervical mass measured $4 \times 4 \mathrm{~cm}$ was palpated on the anterior surface of the cervix. Biopsy of the lesion demonstrated extensive necrosis and was in favor of squamous cell carcinoma. Patient was accepted as FIGO stage $\mathrm{I}_{\mathrm{b} 1-2}$ and underwent type II hysterectomy with bilateral salpingoopherectomy and bilateral pelvic lymph node dissection was carried out. Post operative pathologic evaluation of the surgical specimen evinced that the case was primary cervical choriocarcinoma. Conclusion: Primary choriocarcinoma of the cervix should be considered in patients in their reproductive years with cervical lesion and negative cervical cytology. Beta-hCG assay and transvaginal color Doppler sonography are useful for early diagnosis.
\end{abstract}

Keywords: Choriocarcinoma; Cervix; Primary

\section{Introduction}

Choriocarcinoma was categorized into two classes: gestational and non gestational. Non gestational choriocarcinoma is a rare germ cell tumor of the ovary that only few cases are reported in literature. Gestational choriocarcinoma belongs to the group of the gestational trophoblastic disease (GTD) and usually arises in the uterine cavity. Extrauterine choriocarcinoma is rarely seen. Saito et al. defined following diagnostic criteria for extrauterine choriocarcinoma in 1965: 1) absence of disease in the uterine cavity, 2) exclusion of coexistence of normal intrauterine pregnancy, 3) exclusion of molar pregnancy and 4) pathologic confirmation of disease [1]. Most of the extrauterine choriocarcinoma reported in literature, originates in uterine cervix [2-7]. However, there are also reports in the literature that choriocarcinoma located in other regions outside the uterus in genital tract such as ovary [8], tube [9], vulva [10] and vagina [11]. Our objective was to describe the clinical and pathologic findings of one case of primary cervical choriocarcinoma in a 35-year-old woman and reviews of the literatures.

\footnotetext{
"Corresponding author.
}

\section{Materials and Methods}

From January 1950 to December 2008, a PUBMED/ MEDLINE search performed using the key words choriocarcinoma and cervix and primary. Totally 29 publications including 78 patients existed (Table 1), which 18 are in the PUBMED/MEDLINE. In our review, we excluded all papers other than English language. We got information regarding age, gravida and parity, symptoms and duration, preceding pregnancy, latent period from preceding pregnancy, location, lesion size and hCG level (Table 2). Also type of therapy and the outcomes were attained and mentioned in separate table (Table 3).

\section{Case Presentation}

A 35-year old woman, Gravid 3, Para 2 and Abortion 1, had been experienced irregular vaginal bleeding for 7 months when she was referred to our clinic on June 2008. Her first and second pregnancy ended in a full-term delivery by caesarean section in 37 and 38 weeks of gestation in 2002 and 2004, respectively. Her third pregnancy ended in a missed abortion at 6 week's gestation in 2005 . She mentioned a regular menstrual cycle with 7 days mean duration. She complained of bleeding 4 days before her menses, and in the last month, she mentioned con- 
Table 1. Eighty-seven cases of primary cervical choriocarcinoma recorded in literature.

\begin{tabular}{|c|c|c|c|}
\hline Study & Cases & Journal & Language/Country \\
\hline Rashbaum $\mathrm{M}^{*}(1952)$ & 13 (12 from literature) & Am J Obstet Gynecol 1952; 64: 451-5 & English/America \\
\hline Saito M (1965) & 18 (18 from literature) & World Obstet Gynecol 1965; 17: 459-84 & Japanese/Japan \\
\hline Minegishi (1965) & 6 & Sanfujinka Jissai 1965; 14: 763-7 & Japanese/Japan \\
\hline Koga (1966) & 1 & J Jpn Obstet Gynecol Soc 1966; 13: 245-9 & Japanese/Japan \\
\hline Ooguchi (1966) & 7 & J Jpn Obstet Gynecol Soc 1966; 18: 1083-92 & Japanese/Japan \\
\hline Danek (1969) & 1 & Minerva Ginecol 1969; 21: 1707-11 & Italian/Italy \\
\hline Momose (1970) & 1 & Obstet Gynecol Ther 1970; 21: 468-71 & Japanese/Japan \\
\hline Pavlica (1971) & 1 & Zentralbl Gynakol 1971; 93: 72-4 & German/Germany \\
\hline Tsukamoto* $(1980)$ & 1 & Gynecol Oncol 1980; 9: 99-107 & English/Japan \\
\hline Tripathi $^{*}(1982)$ & 1 & Br J Obstet Gynecol 1982; 89: 267-9 & English/India \\
\hline Meriah (1983) & 1 & J Gynecolo Obstet Biol Reprod(Paris) 1983; 12: 519-24 & French/France \\
\hline $\operatorname{Martin}^{*}(1983)$ & 1 & Am J Obstet Gynecol 1983; 147: 343-4 & English/America \\
\hline Bogdanowicz (1984) & 1 & Ginekol Pol 1984; 55: 527-30 & Polish/Poland \\
\hline Bhalla* (1987) & 1 & Indian J Pathol Microbiol 1987; 30: 51-3 & English/India \\
\hline Tsai*(1988) & 4 & Asia Oceania J Obstet Gynaecol 1988; 14: 285-92 & English/Taiwan \\
\hline Ben-Chetrit $^{*}(1990)$ & 1 & Am J Obstet Gynecol 1990; 163: 1161-3 & English/Israel \\
\hline Lee $^{*}(1992)$ & 1 & Acta Obstet Gynecol Scand 1992; 71: 479-81 & English/Taiwan \\
\hline Heyn (1993) & 1 & Geburtshilfe Frauenheilkd 1993; 53: 498-500 & German/Germany \\
\hline Herts $^{*}(1993)$ & 1 & J Ultrasound Med 1993; 12: 59-62 & English/America \\
\hline Abboud (1994) & 1 & J Gynecol Obstet Biol Reprod (paris) 1994; 23: 149-51 & French/France \\
\hline Al Hassani* (1995) & 1 & Trop Geogr Med 1995; 47: 308-9 & English/Qatar \\
\hline Yahata* (1997) & 1 & Gynecol Oncol 1997; 64: 274-8 & English/Japan \\
\hline Lema $^{*}(1997)$ & 1 & East Afr Med J 1997; 74: 600-2 & English/Malawi \\
\hline Baykal $^{*}(2003)$ & 1 & Gynecol Oncol 2003; 90: 667-9 & English/Turkey \\
\hline Huang (2004) & 2 & Zhong Nan Da Xue Xue Bao Yi Xue Ban 2004; 29: 108-9 & Chineese/China \\
\hline Roopnarinesingh $^{*}$ (2004) & 1 & Ir Med J 2004; 97: 147-8 & English/Irland \\
\hline Peko (2005) & 1 & Med Trop 2005; 65: 498 & French/France \\
\hline $\mathrm{Fu}^{*}(2007)$ & 4 & Int J Gynecol Cancer 2007; 17: 715-719 & English/China \\
\hline Kairi-Vassilatou* ${ }^{*}(2007)$ & 1 & Int J Gynecol Cancer 2007; 17: 921-925 & English/Greece \\
\hline
\end{tabular}

tinuous spotting for one month. On physical examination, necrotic hemorrhagic polypoid mass protruding into cervical canal, approximately $4 \times 4 \mathrm{~cm}$, was palpated. Vaginal fornices were normal. Digital examination demonstrated no parametrial extension. Colposcopy was done and punch biopsy was taken. During biopsy significant bleeding from the lesion occurred and because of obscured vision only eight specimens were excised. Pathology reported that six of eight specimens were necrotic tissue with atypia in favor of squamous cell carcinoma and two specimens demonstrated dysplasia.

On investigation, Biochemistry profile and chest $\mathrm{X}$ ray (postero-anterior) were within normal limits. Computed tomography of the abdomen and pelvic were normal. No metastasis was found. Abdominal sonography showed normal structures with uterus in normal size and normal endometrium. Intravenous pyelography, cystoscopy and proctoscopy were within normal as well. Then, the pa- 
Table 2. Clinical featured of the patients with primary cervical choriocarcinoma in the literature.

\begin{tabular}{|c|c|c|c|c|c|c|c|c|}
\hline Study & Age & $\begin{array}{l}\text { Gravida } \\
\text { and Para }\end{array}$ & Symptoms & $\begin{array}{l}\text { Preceding } \\
\text { Pregnancy }\end{array}$ & $\begin{array}{l}\text { Latent Period } \\
\text { form Preceding } \\
\text { Pregnancy }\end{array}$ & Location & Lesion Size & $\begin{array}{l}\text { Serum or Urine } \\
\text { hCG }\end{array}$ \\
\hline Rashbaum (1952) & 38 & G6P4 & $\begin{array}{l}\text { Vaginal Bleeding + } \\
\text { Abdominal pain } \\
\text { (2 weeks) }\end{array}$ & $\begin{array}{l}\text { Induced } \\
\text { abortion }\end{array}$ & 11 months & $\begin{array}{l}\text { Posterior } \\
\text { wall }\end{array}$ & $\begin{array}{c}6 * 8 * 4 \mathrm{~cm} \\
\text { (macrography) }\end{array}$ & - \\
\hline Tsukamoto (1980) & 49 & G4P2 & $\begin{array}{l}\text { Vaginal spotting + } \\
\text { lower abdominal } \\
\text { pain ( } 2 \text { weeks) }\end{array}$ & $\begin{array}{l}\text { Elective } \\
\text { abortion }\end{array}$ & 36 months & - & $\begin{array}{l}4.5 * 3.5 \mathrm{~cm} \\
\text { (Pelvic } \\
\text { angiography) }\end{array}$ & $8000 \mathrm{U} / \mathrm{L}$ \\
\hline Tripathi (1982) & 28 & G2P2 & $\begin{array}{l}\text { Menorrhagia (7 } \\
\text { months) }\end{array}$ & $\begin{array}{c}\text { Term } \\
\text { delivery }\end{array}$ & 7 months & - & $\begin{array}{l}6 * 5 * 2.5 \mathrm{~cm} \\
\text { (macrography) }\end{array}$ & 540,000 i. u/24 h \\
\hline Martin (1983) & 35 & G1P1 & $\begin{array}{l}\text { Menorrhagia } \\
\text { (3 months) }\end{array}$ & $\begin{array}{c}\text { Term } \\
\text { delivery }\end{array}$ & 12 months & - & $\begin{array}{c}4.0 * 3.5 * 2.5 \mathrm{~cm} \\
\text { (macrography) }\end{array}$ & $\begin{array}{c}\text { Positive but not } \\
\text { mentioned }\end{array}$ \\
\hline Bhalla (1987) & 30 & G4P3 & $\begin{array}{l}\text { Vaginal bleeding } \\
\text { (7 weeks) }\end{array}$ & $\begin{array}{l}\text { Induced } \\
\text { abortion }\end{array}$ & 12 months & - & $\begin{array}{c}6 * 5 * 4 \mathrm{~cm} \\
\text { (macrography) }\end{array}$ & $\begin{array}{l}\text { Positive with } \\
\text { dilution } 1 / 32\end{array}$ \\
\hline Case 1 & 46 & G7P4 & $\begin{array}{c}\text { Menorrhagia with } \\
\text { occasionally massive } \\
\text { bleeding ( } 2 \text { months) }\end{array}$ & $\begin{array}{l}\text { Elective } \\
\text { abortion }\end{array}$ & 48 months & - & $\begin{array}{c}9 * 7 * 4 \mathrm{~cm} \\
\text { (macrography) }\end{array}$ & $162,250 \mathrm{mIU} / \mathrm{ml}$ \\
\hline \multirow{2}{*}{$\begin{array}{c}\text { Tsai } \\
\text { (1988) }\end{array}$} & 43 & G1P1 & Hemorrhagic shock & Term delivery & 29 years & $\begin{array}{l}\text { Posterior } \\
\text { wall }\end{array}$ & $3 \mathrm{~cm}$ & $\begin{array}{l}\text { Positive but not } \\
\text { mentioned }\end{array}$ \\
\hline & 29 & G4P3 & $\begin{array}{c}\text { Menorrhagia } \\
\text { (several months) }\end{array}$ & $\begin{array}{l}\text { Induced } \\
\text { abortion }\end{array}$ & 48 months & - & - & $\begin{array}{l}\text { Positive but not } \\
\text { mentioned }\end{array}$ \\
\hline Case 4 & 53 & G7P5 & - & $\begin{array}{l}\text { Hydatidiform } \\
\text { mole }\end{array}$ & 3 months & - & - & - \\
\hline Ben-Chetrit (1990) & 33 & G3P3 & $\begin{array}{l}\text { Menorrhagia } \\
\text { (1 month) }\end{array}$ & Term delivery & 12 months & - & $\begin{array}{l}0.5 * 1 \mathrm{~cm} \text { (pelvic } \\
\text { examination) }\end{array}$ & $32 \mathrm{mIU} / \mathrm{ml}$ \\
\hline Lee (1992) & 29 & G2P1 & $\begin{array}{c}\text { Profuse vaginal } \\
\text { bleeding (6 hours) }\end{array}$ & $\begin{array}{l}\text { Hydatidiform } \\
\text { mole }\end{array}$ & 9 months & Left wall & $\begin{array}{l}8.6 * 7.7 \mathrm{~cm} \\
\text { (sonography) }\end{array}$ & $150,580 \mathrm{mIU} / \mathrm{ml}$ \\
\hline al Hassani (1994) & 40 & G3P3 $3^{(a)}$ & $\begin{array}{l}\text { Post-coital bleeding } \\
\text { ( } 2 \text { months })\end{array}$ & Term delivery & - & $\begin{array}{l}\text { Anterior } \\
\text { lip }\end{array}$ & $\begin{array}{c}2.5 * 2 \mathrm{~cm} \\
\text { (macrography) }\end{array}$ & $244 \mathrm{IU} / \mathrm{L}$ \\
\hline Yahata (1997) & 38 & G4P2 & $\begin{array}{l}\text { Menorrhagia } \\
\text { ( } 2 \text { weeks) }\end{array}$ & Term delivery & 4 months & - & $\begin{array}{c}6 * 5 \mathrm{~cm} \text { (Doppler } \\
\text { sonography and } \\
\text { MRI) }\end{array}$ & $128,000 \mathrm{IU} / \mathrm{L}$ \\
\hline Lema (1997) & 36 & G11P10 & $\begin{array}{l}\text { Vaginal bleeding in } \\
28 \text { weeks of } \\
\text { gestation ( } 2 \text { days) }\end{array}$ & Term delivery & 24 months & $\begin{array}{l}\text { Posterior } \\
\quad \text { lip }\end{array}$ & $\begin{array}{c}4 * 2 \mathrm{~cm} \\
\text { (macrography) }\end{array}$ & - \\
\hline Baykal (2003) & 54 & G5P4 & $\begin{array}{l}\text { Postmenopausal } \\
\text { bleeding }\end{array}$ & Term delivery & 17 years & - & $\begin{array}{c}3 \mathrm{~cm} \text { (pelvic } \\
\text { examination) }\end{array}$ & $\begin{array}{l}\text { 45,000 IU/L } \\
\text { after pathology } \\
\text { report }\end{array}$ \\
\hline $\begin{array}{c}\text { Roopnarinesingh } \\
\text { (2004) }\end{array}$ & 25 & G1p0 & $\begin{array}{l}\text { Abdominal pain and } \\
\text { mild vaginal } \\
\text { bleeding ( } 2 \text { months) }\end{array}$ & $\begin{array}{l}\text { Hydatidiform } \\
\text { mole }\end{array}$ & 24 months & $\begin{array}{l}\text { Anterior } \\
\text { lip }\end{array}$ & $\begin{array}{c}4 * 3 * 5 \mathrm{~cm} \\
(\mathrm{MRI})\end{array}$ & $4150 \mathrm{U} / \mathrm{L}$ \\
\hline \multirow{3}{*}{ Fu (2007) } & 46 & G6P4 & $\begin{array}{l}\text { Vaginal bleeding } \\
\text { (4 months) }\end{array}$ & $\begin{array}{l}\text { Induced } \\
\text { abortion }\end{array}$ & 64 months & $\begin{array}{l}\text { Posterior } \\
\text { cervix }\end{array}$ & $\begin{array}{c}3 * 4 \mathrm{~cm} \\
\text { (macrography) }\end{array}$ & $20,000 \mathrm{U} / \mathrm{L}$ \\
\hline & 21 & G1P0 & $\begin{array}{l}\text { Vaginal bleeding } \\
\text { (8 months) }\end{array}$ & $\begin{array}{l}\text { Hydatidiform } \\
\text { mole }\end{array}$ & 20 months & $\begin{array}{l}\text { Posterior } \\
\text { cervix }\end{array}$ & $\begin{array}{c}5 * 7 \mathrm{~cm} \\
\text { (macrography) }\end{array}$ & 5344 U/L \\
\hline & 35 & G4P2 & $\begin{array}{l}\text { Vaginal bleeding } \\
\text { (1 month) }\end{array}$ & $\begin{array}{l}\text { Induced } \\
\text { abortion }\end{array}$ & 47 months & $\begin{array}{l}\text { Posterior } \\
\text { cervix }\end{array}$ & $\begin{array}{c}2 * 3 \mathrm{~cm} \\
\text { (macrography) }\end{array}$ & $4000 \mathrm{U} / \mathrm{L}$ \\
\hline Case 4 & 30 & G3P2 & $\begin{array}{l}\text { Vaginal bleeding } \\
\text { (3 months) }\end{array}$ & Term delivery & 12 months & $\begin{array}{l}\text { Posterior } \\
\text { cervix }\end{array}$ & $\begin{array}{l}3.4 * 2.5 \mathrm{~cm} \\
\text { (sonography) }\end{array}$ & $2764 \mathrm{U} / \mathrm{L}$ \\
\hline $\begin{array}{c}\text { Kairi-Vassilatou } \\
(2007)\end{array}$ & 43 & G7P2 & $\begin{array}{l}\text { Amenorrhea } \\
\text { ( } 2 \text { months) }\end{array}$ & Term delivery & 12 months & $\begin{array}{l}\text { Posterior } \\
\text { cervix }\end{array}$ & $\begin{array}{c}5 * 3 \mathrm{~cm} \\
\text { (macrography) }\end{array}$ & 7485 mIU/ml \\
\hline
\end{tabular}

(a): Patient had amenorrhea 3 years before her symptoms and D \& C was performed for patient, but there was no report of the pathology. So the gravida is subject to change (G4). 
Table 3. Staging, treatment and outcomes of the patients with primary cervical choriocarcinoma in the literature.

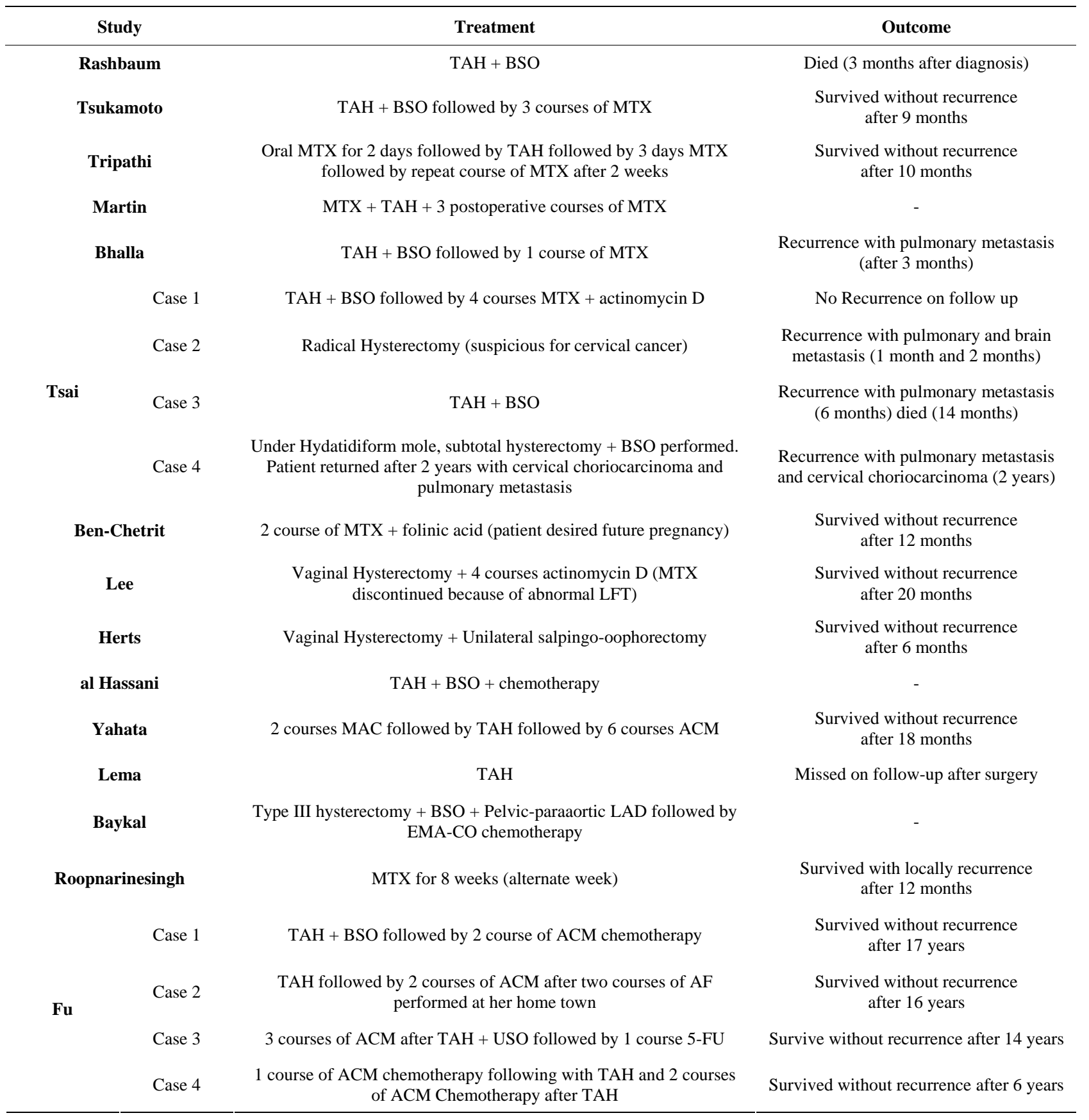

-: No information, ACM: Actinomycin D, cyclophosphamide and methotrexate; AF: Actinomycin D and 5-Fluouracil; BSO: Bilateral salpingo-oophorectomy; EMA-CO: Etoposide-methotrexate-dactinomycin-cyclophosphamide-vincristine; 5-FU: 5-fluouracil; LAD: Lymphadenectomy; LFT: Liver function test; MTX: Methotrexate; TAH: Total abdominal hysterectomy; USO: Unilateral salpingo-oophorectomy.

tient was accepted as FIGO stage $\mathrm{Ib}_{1-2}$ cervical cancer. One week later the patient underwent type II hysterictomy with bilateral salpingoopherectomy and pelvic lymph node dissection. At operation, a soft necrotic hemorrhagic mass, approximately $4 \times 5 \mathrm{~cm}$, was found on the anterior surface of the cervix.

On gross examination, the hysterectomy specimen presented with a soft, brown-colored mass of $3.5 \mathrm{~cm}$ in the largest diameter which was intramural and did not involve the lumen. The tumor formed a necrotic hemorrhagic mass confined to the lower part of cervix without extending to the endometrium or myometrium.

On microscopic examination sections revealed a necrotic hemorrhagic tumor that is distinct from the epithelial surface of both endocervix and ectocervix. So, this distinction proved that tumor had not had epithelial ori- 
gin and we could exclude Squamous cell carcinoma or adenocarcinoma. On magnification Malignant trophoblastic tumor composed of atypic bizarre polygonal trophoblasts with nucleolated nuclei, High nuclear to cytoplasm ratio (N/C ratio) and atypic mitotic figures which are strongly positive for B-HCG and pancytokeratin. Human placental lactogen (HPL) was weakly positive in few cells. There was also hemorrhage (Blood Lake) in tissue and for this reason, the pathologist performed Immunohistochemistry of CD31 and VIII Factor to exclude tumor with endothelial origin like angiosarcoma. Based on these findings, choriocarcinoma was diagnosed for the patient. An extensive sectioning of the endometrium, myometrium, parametrial tissues and lymph nodes confirmed that these areas were free of neoplastic cells or any other site of trophoblastic cells.

Patient discharged with good condition four days later and postoperative B-hCG was $6 \mathrm{mIU} / \mathrm{ml}$ after 2 weeks of operation. According to the FIGO staging system of GTD, the patient was classified as stage I, but because there was no preoperative B-hCG level we could not determine the risk score of the patient [12]. The patient is under follow-up and has had serial B-hCG measurement, which has been declining through 4 weeks. She is doing well without any complain so far.

\section{Discussion}

Gestational intrauterine choriocarcinoma has higher incidence rate in Asia, Africa and Latin America in comparison to United States and Europe, may be due to socioeconomic status [13]. However, the overall incidence of choriocarcinoma in recent years has been decreased parallel to improving socioeconomic conditions [13]. Primary choriocarcinoma of the cervix is an extremely rare disease; however, most of the case reports in literatures demonstrate that extrauterine choriocarcinoma mostly originates in cervix rather than other sites in genital tract [2-7]. Our case fulfilled the criteria defined by Saito et al. [1]. So, it is an ectopic choriocarcinoma originates from the cervix.

The median age was 37 with the range of 21 - 54 years old (two patients were postmenopausal). 9 patients were less than 35 years old. The latent period from preceding pregnancy had a range of 3 - 348 months with $62 \%$ less than or equal to 24 months. Long latency of choriocarcinoma after the preceding pregnancy is not common [14]. Choriocarcinoma is heterochronic if the latent period is more than two years [15]. Choriocarcinoma occurred in our patients 3 years after the preceding pregnancy, which was terminated by induced abortion. There was limited data regarding the location of tumor with mostly originated from posterior cervix.

Gestational choriocarcinoma may follow any type of pregnancy, which most preceded by molar pregnancy (50\%), 25\% developed after abortion and 25\% follow an apparently normal pregnancy. The more common gestational variety is associated with a coincident and antecedent pregnancy. In this review primary cervical choriocarcinoma preceded by 50\% normal pregnancy, 32\% abortion and $18 \%$ developed after hydatidiform mole.

There are some theories expressed for developing of cervical choriocarcinoma $[16,17]$. It is possible that it can be a metastatic tumor from a vanishing intrauterine choriocarcinoma or it could be a transformation of a cervical pregnancy. The pathologic examination ruled out these possibilities, as we demonstrated that no trophoblastic cell was observed in endothelium and myometrium of the uterus. Another theory expresses the role of therapeutic abortion in the implantation of trophoblasts in the cervix and lower genital tract. Trauma to the cervix during D \& C may be a predisposing factor [6]. Our case was preceded by an abortion and it supports the later theory. There was no pathological examination of the curetted material as this was performed in another city and we did not have access to the pathology.

The clinical diagnosis of primary choriocarcinoma is very difficult. In this review all patients except one, complained of vaginal bleeding with different period of time ranged from 6 hours to 8 months, with different severity that one patient referred with hypovolemic shock. Only one patient complained of amenorrhea. The predominant symptom is abnormal vaginal bleeding which is due to angiogenesis and neovasculirization of this tumor. There are few differential diagnoses which include uterine cervical pregnancy, threatened abortion, a cervical polyp and malignancy [4]. In the present case, choriocarcinoma was presented with vaginal bleeding and misdiagnosed as malignancy. For this reason, we should consider choriocarcinoma as differential diagnosis in any patient in their reproductive years with a cervical lesion with high vascularity and profuse bleeding.

How can we suspect and diagnose cervical choriocarcinoma? As we mentioned above, in cervical lesions in women of child-bearing age with profuse bleeding, measurement of serum and urinary B-hCG is useful for diagnosis. Color Doppler transvaginal ultrasonography and MRI with contrast detect the abundant blood flow in the tumor [4]. Transvaginal Doppler sonography allows detection of tumoral vessels, which manifests high diastolic blood flow and low impedance resulting in neovasculirization [4]. Contrast-enhanced MRI can demonstrate tumoral vascularity and in cases of necrosis hypointensity of the necrotic areas are perceptible [4].

Diagnosis of such a kind of cervical tumor is very difficult for pathologist both in biopsy and surgical resection. In our case, the first pathologist misdiagnosed choriocarcinoma with squamous cell carcinoma as Ben- 
Chetrit [18]. Necrosis is a predominant feature of these neoplasms, often to such an extent that the viable tissue is obscured. So, we should consider immunohistochemical staining in extend necrotic tissue obtained from cervix for more information, because there is the chance for more limited surgery and more successful chemotherapy for choriocarcinoma if it is diagnosed in the first step. In our case, massive necrosis of the tumor and arising of tumor from non-epithelial origin motivate the pathologist to perform immunohistochemical staining. As we showed the specimen was markedly positive for B-hCG.

The treatment of choice as in our patient was total abdominal hysterectomy and bilateral salpingoopherectomy with or without chemotherapy. Interestingly, Ben-Chetrit and his co-workers in one report and Roopnarinesingh et $a l$. in other report, documented conservative management of primary cervical choriocarcinoma $[4,18]$.

\section{Conclusion}

In conclusion, cervical choriocarcinoma should be considered in the differential diagnosis of cervical lesions in their child-bearing years, especially lesions with prominent vascularity. A beta-hCG assay, transvaginal color Doppler sonography or contrast-enhanced MRI may form part of pre-operative investigation in such a patient. A detailed correlation between histologic findings and patient's clinical history, lab studies and radiologic data is always required to preclude diagnostic pitfalls and designates the appropriate treatment.

\section{REFERENCES}

[1] M. Saito, T. Azuma and K. Nakamura, "On Ectopic Choriocarcinoma,” World Journal of Obstetrics and Gynecology, Vol. 17, 1965, pp. 459-484.

[2] C. Baykal, G. Tulunay, D. Bulbul, N. Boran and M. F. Kose, "Primary Choriocarcinoma of the Uterine Cervix in a Postmenopausal Patient: A Case Report," Gynecologic Oncology, Vol. 90, No. 3, 2003, pp. 667-669. http://dx.doi.org/10.1016/S0090-8258(03)00369-X

[3] Y. Fu, W. Lu, C. Zhou and X. Xie, "Primary Cervical Choriocarcinoma: Report of Four Cases and Literature Review," International Journal of Gynecological Cancer, Vol. 17, No. 3, 2007, pp. 715-719. http://dx.doi.org/10.1111/j.1525-1438.2007.00819.x

[4] T. Yahata, S. Kodama, H. Kase, N. Sekizuka, T. Kurabayashi, Y. Aoki and K. Tanaka, "Primary Choriocarcinoma of the Uterine Cervix: Clinical, MRI, and Color Doppler Ultrasonographic Study," Gynecologic Oncology, Vol. 64, No. 2, 1997, pp. 274-278. http://dx.doi.org/10.1006/gyno.1996.4541

[5] R. Roopnarinesingh, S. Igoe and J. E. Gillan, "Choriocarcinoma-Presenting as a Primary Lesion of the Cervix," Irish Medical Journal, Vol. 97, 2004, pp. 147-148.
[6] S. S. Al Hassani and G. C. Ejeckam, "Primary Cervical Choriocarcinoma,” Tropical and Geographical Medicine, Vol. 47, 1995, pp. 308-309.

[7] B. R. Herts, J. M. Yee and R. F. Porges, "Primary Cervical Choriocarcinoma: Case Report and Review of Literature,” Journal of Ultrasound in Medicine, Vol. 12, 1993, pp. 59-62.

[8] N. P. Veridiano, D. Gal, I. Delke, Y. Rosen and M. L. Tancer, "Gestational Choriocarcinoma of the Ovary," Gynecologic Oncology, Vol. 10, No. 2, 1980, pp. 235-240. http://dx.doi.org/10.1016/0090-8258(80)90087-6

[9] M. G. Muto, J. M. Lage, R. S. Berkowitz, D. P. Goldstein and M. R. Bernstein, "Gestational Choriocarcinoma Disease of the Fallopian Tube,” Journal of Reproductive Medicine, Vol. 36, 1991, pp. 57-60.

[10] S. Weiss, A. Amit, M. R. Schwartz and A. L. Kaplan, "Primary Choriocarcinoma of the Vulva," International Journal of Gynecological Cancer, Vol. 11, No. 3, 2001, pp. 251-254.

http://dx.doi.org/10.1046/j.1525-1438.2001.01005.x

[11] H. Sonobe, K. Taguchi, K. Ogawa and T. Yoshioka, "Latent Vaginal Choriocarcinoma in a Postmenopausal Woman,” Acta Pathologica Japonica, Vol. 26, 1976, pp. 611-618.

[12] FIGO Oncology Committee Report, "FIGO Staging for Gestational Trophoblastic Neoplasia 2000,” International Journal of Gynecology \& Obstetrics, Vol. 77, No. 3, 2002, pp. 285-287.

http://dx.doi.org/10.1016/S0020-7292(02)00063-2

[13] P. Y. Wel snd P. C. Ouyang, "Trophoblastic Disease in Taiwan: A Review of 157 Cases on a 10-Year Period,” American Journal of Obstetrics \& Gynecology, Vol. 85, 1963, pp. 844-849.

[14] P. C. Dyke and L. M. Fink, "Latent Choriocarcinoma," Cancer, Vol. 20, No. 1, 1967, pp. 150-154. http://dx.doi.org/10.1002/1097-0142(1967)20:1<150::AI D-CNCR2820200121>3.0.CO;2-9

[15] W. Park, “Choriocarcinoma: A Study of Its Pathology,” F. A. Davis, Philadelphia, 1971.

[16] N. Tsukamoto, M. Nakamura, M. Kashimura and T. Saito, "Primary Cervical Choriocarcinoma," Gynecologic Oncology, Vol. 9, No. 1, 1980, pp. 99-107. http://dx.doi.org/10.1016/0090-8258(80)90014-1

[17] E. Kairi-Vassilatou, K. Papakonstantinou, D. Grapsa, A. Kondi-Paphiti and D. Hasiakos "Primary Gestational Choriocarcinoma of the Uterine Cervix," International Journal of Gynecological Cancer, Vol. 17, No. 4, 2007, pp. 921-925. http://dx.doi.org/10.1111/j.1525-1438.2006.00852.x

[18] A. Ben-Chetrit, S. Yagel, I. Ariel, D. Zacut, S. Shimonovitz and D. Ceinikier-Hochner, "Successful Conservative Management of Primary Nonmetastatic Cervical Choriocarcinoma," American Journal of Obstetrics \& Gynecology, Vol. 163, No. 4, 1990, pp. 1161-1163. http://dx.doi.org/10.1016/0002-9378(90)90679-2 